\title{
Tweede NVMO-Promovendidag
}

\section{Inleiding en hoofdlezingen}

"Een dag om te netwerken, en over hoe 'net' te werken", zo begon Monica van de Ridder (UMCU). Een mooi begin van de tweede NVMO-promovendidag op 15 juni 2007: netwerken met medepromovendi en met elkaar te letten op onderzoekskwaliteit. Deze dag is een goed moment om andere promovendi te ontmoeten en nieuwe ideeën op te doen. Deze keer waren 54 deelnemers aanwezig: 37 promovendi en 17 promotoren, begeleiders en andere belangstellenden.

De lezingen verzorgden Diana Dolmans (UM) en Albert Scherpbier (UM). Diana Dolmans bepleitte verdere professionalisering van het medisch onderwijs. Hierin sprak zij over het belang van het lezen van artikelen buiten het medische vakgebied. Verder zag zij graag meer plaats voor design-based research. Albert Scherpbier gaf een overzicht van belangrijke topics voor onderzoek in de komende jaren. Vooral de vervolgopleidingen zouden meer aandacht moeten krijgen in onderzoek.

\section{Parallelle sessies}

Ook op deze promovendidag kregen promovendi de mogelijkheid om over eigen onderzoek van gedachten te wisselen. Promovendi konden hun onderzoeksproject presenteren en bepaalde problemen uit hun onderzoek voorleggen aan de aanwezigen. Om dit alles in goede banen te leiden werden zeven thematische parallelle sessies georganiseerd rond de thema's: simulatiepatiënten en arts-patiëntcommunicatie in consultatietraining, leerprocessen in het medisch onderwijs, onderwijs en toetsing, leeromgevingen, professionele ontwikkeling, computergestuurd onderwijs en werkplek leren.

Deze sessies waren verspreid over een ochtendronde en een middagronde. Elke spreker kreeg een kwartier spreektijd: tien minuten voor presentatie, gevolgd door vijf minuten discussie.

De sessies gaven een goed beeld van de verschillende soorten onderzoek en voor de promovendi was het een interessante ervaring om hun onderzoek te presenteren aan collega-onderzoekers.

\section{Promotiesimulatie}

Nieuw op deze promovendidag was de promotiesimulatie. Daarin werden drie laatstejaars promovendi aan de tand gevoeld over één van de artikelen waarop zij promoveren. Jongerejaars fungeerden daarbij als hun opponenten.

Marc Soethout (VUMC) ging in op de vraag hoe de interesse van studenten in een carrière op het terrein van volksgezondheid zich tijdens de medische opleiding ontwikkelt en wat de betekenis daarvan is, gegeven het aantal studenten dat in die sector terechtkomt. Bij Debbie Jaarsma (UU) stond de ontwikkeling en het gebruik van een beoordelingsinstrument centraal waarmee onderzoeksverslagen van studenten beter kunnen worden beoordeeld. Tenslotte bood Nigel Turner (UMCU) een kijkje in de effecten van de Advanced Paediatric Life Support cursus op het inzicht en vertrouwen van deelnemers in eigen kunnen, en de mate waarin zij de verworven vaardigheden nadien ook werkelijk gebruikten. 
Voor de laatstejaars bood deze simulatie gelegenheid om te oefenen met het helder en bondig uiteenzetten van eigen onderzoek en resultaten, en het accuraat reageren op oppositie. Voor de jongerejaars was het een mooie kans te oefenen met 'critical appraisal' van een artikel en de vertaling daarvan naar vragen voor het wetenschappelijke debat. Het publiek kreeg, in kritisch-constructieve sfeer, een interessant zicht op drie promotieonderzoeken die recent hebben plaatsgevonden of zich in de laatste fase bevinden.

\section{Afsluiting en schriftelijke evaluatie}

Bas Koole (UGent), Willems Koops (MMC), Mariska Min-Leliveld (LUMC), Stephan Ramaekers (UU) verzorgden een terugblik op de dag en gaven een aanzet tot netwerken. Elke deelnemer kreeg een halve ansichtkaart in handen met de opdracht tijdens de afsluitende borrel de persoon op te zoeken die de andere helft had.

Uit de schriftelijke evaluatie blijkt dat de dag geslaagd was: deelnemers schrijven dat de dag 'zinvol' is, er is 'enthousiasme van allen', en een 'rijke schakering aan onderwerpen'.

Uit de evaluatie blijkt dat het belangrijkste aandachtspunt voor de volgende promovendidag tijd is. Vijftien minuten voor presentatie en discussie is kort; de diepgang in discussies ontbreekt. Gesuggereerd wordt per spreker twintig minuten te geven: tien minuten presentatie en tien minuten discussie. Deelnemers gaven aan dat er weinig tijd was om te 'netwerken': lunchtijd en pauzes waren kort. De promotiesimulaties waren leuk, maar één vraag per simulatie is voldoende.
Deelnemers gaven verschillende suggesties voor alternatieve bespreekvormen: 'open space conferentie', rondetafelsessies over een specifiek onderzoeksonderwerp, uitwisseling via een internetforum, en samenstellen gespreksgroepen rondom verwante onderwerpen. De evaluatie leverde verder een zevental namen op van promovendi die nog niet in het promovendinetwerk zijn opgenomen. Voor de promovendidag 2008 liggen er nog voldoende uitdagingen!

\section{Aankondiging derde NVMO-Promo- vendidag, Utrecht 18 april 2008}

Op 18 april 2008 staat de derde Medisch Onderwijskundige Promovendidag gepland. Eén van de plenaire sessies wordt verzorgd door Janke Cohen-Schotanus uit het Universitair Medisch Centrum te Groningen. De andere plenaire activiteit wordt verzorgd door collega's uit Maastricht.

Als er voldoende belangstelling is wordt er tijdens de lunchpauze een tweetal rondetafelsessies georganiseerd op zowel het gebied van kwalitatief als van kwantitatief onderzoek.

Promovendi kunnen een korte presentatie over lopend onderzoek houden, en voor de promovendi in hun laatste jaar is er opnieuw de gelegenheid om aan een promotiesimulatie deel te nemen.

De NVMO-Promovendidag begint om 9.30 uur met koffie en heeft plaats in het Universitair Medisch Centrum te Utrecht.

Bas Koole, Mariska Min-Leliveld, Stephan Ramaekers en Monica van de Ridder 